\title{
CRISE ECONÔMICA E DIREITOS SOCIAIS: UMA ANÁLISE SOBRE A CONSTITUCIONALIDADE DE RESTRIÇÕES A DIREITOS PRESTACIONAIS
}

\author{
ANNA CAROLINA MigueIs PEREIRA ${ }^{\dagger}$
}

\begin{abstract}
RESUMO: O escopo do presente trabalho reside em verificar se, em momentos de grave crise econômica, as medidas de austeridade que restrinjam direitos fundamentais, especialmente os de cunho social, podem ser consideradas constitucionalmente válidas, à luz do pragmatismo jurídico e da realidade fática e econômica em que são editadas. Para tanto, investigaremos se princípios como isonomia e vedação ao retrocesso podem ser considerados impeditivos a essas restrições, bem como buscaremos oferecer parâmetros para a análise da validade jurídica de tais medidas. A partir dessa moldura, pretendemos demonstrar que, embora haja margem para a conformação do direito pela realidade, as ações de enfrentamento a crises econômicas não podem ser consideradas espaços ajurídicos, devendo ser permeadas por valores caros ao ordenamento, sobretudo a dignidade da pessoa humana e a democracia participativa. Por fim, pretendemos trazer balizas para contextos em que, diante da gravidade do cenário de crise, o mínimo existencial não possa ser resguardado, visando a seu restabelecimento ou, ao menos, ao não agravamento da situação de escassez.
\end{abstract}

Palavras-Chave: Crise Econômica; Direitos Sociais; Restrições; Constitucionalidade.

\footnotetext{
† Doutoranda e Mestre em Direito Público pela Universidade do Estado do Rio de Janeiro (UERJ), Especialista em Direito do Estado e da Regulação pela Fundação Getúlio Vargas (FGV - Direito Rio), Professora Convidada da Pós-Graduação e de Cursos de Extensão da FGV - Direito Rio e Procuradora do Estado do Rio de Janeiro.
} 


\begin{abstract}
The scope of the present article is to analyze whether austerity measures developed during severe economic crises that arise restrictions to social and fundamental rights may be considered valid under the basis of the Legal Pragmatism. In order to achieve these goals, we intend to investigate if general principles such as equality and the prohibition to the "ratchet effect" may prevent these measures to the adopted, as well as to offer parameters under which the validation of anticrises actions should be scrutinized. Under these constraints, we intend to demonstrate that, although there may be room to adapt the legal system into the reality, anti-crises measures cannot be seen as nonjuridical spaces; instead, they must be surrounded by basilar values to the Rule of Law, such as human dignity and democracy. Finally, we intend to offer limits and parameters applicable to moments when, due to the severity of the economic crises, the public institutions cannot provide the minimum necessary to guarantee the preservation of human dignity, in order to reestablish it as quickly as possible or, at least, to not deteriorate the scarcity situation.
\end{abstract}

KEYWORDS: Economic Crises; Social Rights; Restrictions;

Constitutionality. 
SUMÁRIO:

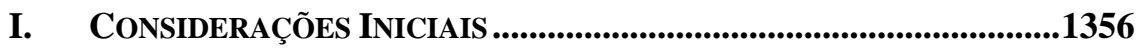

II. ARGUMENTOS CONTRÁRIOS À COMPRESSÃo DE DIREITOS SOCIAIS

EM MOMENTOS DE CRISE.........................................................1356

1. Princípio da Vedação ao Retrocesso......................................1357

2. Princípio da Igualdade .......................................................1359

III. ARguMENTOS FAVORÁ VEIS A RESTRIÇÕES DE DIREITOS SOCIAIS EM MOMENTOS DE CRISE..........................................................................1361

1. A Reserva do Possível, o Núcleo Essencial de Direitos Fundamentais e o Mínimo Existencial ................................1361

2. As versões fracas do Princípio da Proteção à Confiança Legítima e da Proteção ao Direito Adquirido......................1364

3. Pragmatismo Jurídico e Consequencialismo ........................1367

IV. AS MEDIDAS ANTI-CRISE COMO BURACOS NEGROS OU CINZENTOS .................................................................................................1370

V. VIABILIDADE JURÍDICA DE RESTRIÇõES FRACAS A DIREITOS SOCIAIS POR MEDIDAS ANTI-CRISE ECONÔMICA E MECANISMOS DE CONTROLE DESSAS RESTRIÇÕES.....................................................1375

VI. HAVERIA ESPAÇO PARA RESTRIÇÕES FORTES?...................................1381

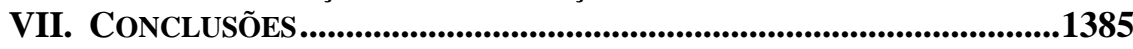

VIII.REFERÊNCIAS ............................................................................1387

\section{TABLE OF CONTENTS:}

I. INICIAL CONSIDERATIONS...............................................................1356

II. ARGUMENTS AGAINST THE COMPRESSION OF SOCIAL RIGHTS IN

MOMENTS OF CRISES .....................................................................1356

1. Principle of Non-Retrocession ................................................1357

2. Principle of Equality ...............................................................1359

III. FAVOURABLE ARGUMENTS TO THE RESTRICTIONS OF SOCIAL RIGHTS IN MOMENTS OF CRISES....................................................1361

1. The Reservation of the Possible, the Essencial Core of

Fundamental Rights and the Minimum of Existance .......1361

2. The weak versions of the Principle of the Legitimate

Expectations and the Protection of the Acquired Right..1364

3. Legal Pragmatism and Consequentialism ...........................1367

IV. THE ANTI-CRISIS MEASURES AS BLACK OR GRAY HOLES..............1370

V. LEGAL FEASIBILITY OF WEAK RESTRICTIONS TO SOCIAL RIGHTS BY ANTI-ECONOMIC CRISIS MEASURES AND MECHANISMS TO CONTROL THESE RESTRICTIONS .................................................1375

VI. IS THERE ANY SPACE FOR STRONG RESTRICTIONS? .........................1381

VII. CONCLUSION .............................................................................................1385

VIII.REFERENCES .......................................................................................................1387 


\section{CONSIDERAÇÕES INICIAIS}

Em momentos de crise econômica, é comum a adoção das chamadas medidas de austeridade, que trazem regras mais rígidas quanto aos gastos públicos, muitas vezes impondo restrições a direitos sociais cuja promoção - embora de inegável relevância - importa despesas consideráveis para o poder público. É nessa situação que podem surgir conflitos entre direitos sociais até então assegurados pela ordem jurídica e ações que o governo pretende implementar no bojo de pacotes de arrocho.

Nesse contexto, passaremos a investigar se a incidência dos princípios constitucionais levaria necessariamente à inconstitucionalidade da medida de austeridade; ou se, ao revés, deve o Direito se mostrar atento à realidade dos fatos e entender ser a medida constitucional, ante a alegação de sua inevitabilidade. Dito de outra forma: analisaremos se seria, ou não, possível admitir uma maior compressão de direitos fundamentais, notadamente os sociais, diante de um contexto de crise econômica severa e imperiosidade de contenção de gastos públicos (o que vem sendo chamado de direito da crise).

\section{Argumentos contrários à COMPRESSÃo De Direitos SOCIAIS EM MOMENTOS DE CRISE}

A maioria dos argumentos contrários à possibilidade de compressão de direitos sociais em situações de crise possui natureza principiológica (igualdade, proporcionalidade, vedação ao retrocesso). Contudo, isso não significa que haja uma facultatividade em considerá-los, dada a reconhecida - ao menos no direito contemporâneo - normatividade dos princípios.

Nesse sentido, não são os princípios meros valores cuja concretização estaria sujeita a preferências pessoais do legislador infraconstitucional ou do administrador público. Antes, instituem a obrigatoriedade da adoção de medidas imperativas à efetivação de um estado de coisas. Os princípios, assim, embora relacionados a valores, com eles não se confundem, em virtude da carga de obrigatoriedade que carregam.

A força normativa dos princípios foi inicialmente defendida no direito alemão por Konrad Hesse em seu famoso trabalho A Força Normativa da Constituição, no qual o autor combate a visão até então vigente de que a Constituição seria um documento político, e não jurídico, desprovido, 
portanto, de eficácia normativa. ${ }^{1}$ Sob este enfoque, a Constituição não seria uma folha de papel, ao contrário das ideias defendidas por Ferdinand Lassalle em 1862. ${ }^{2}$ Hesse rompe com este paradigma, sustentando que os comandos constitucionais seriam vinculantes, dotados de poder de coerção e que, nesse tocante, a Constituição seria, sim, provida de força normativa.

Dessa forma, é possível afirmar que o fato de os argumentos contrários à admissibilidade de restrições a direitos sociais durante crises econômicas terem natureza precipuamente principiológica não afasta, de antemão, a sua validade, uma vez que os princípios, no atual estado de desenvolvimento do Direito, são dotados de força normativa e eficácia irradiante, espraiando-se em direção a todo o ordenamento. A força normativa permite a superação da chamada insinceridade normativa, marcada pela "existência formal e inútil de Constituições que invocam o que não está presente, afirmam o que não é verdade e prometem o que não será cumprido". ${ }^{3}$

Assentada esta premissa, passaremos a analisar, um a um, os princípios que serviriam de fundamento para o afastamento de medidas de enfrentamento a crises econômicas (e a escassez orçamentária que estas em geral trazem a reboque) que restrinjam direitos sociais. Iniciaremos, nesse tocante, com o princípio da vedação ao retrocesso.

\section{Princípio da Vedação ao Retrocesso}

O debate acerca da proibição do retrocesso já se encontra bastante consolidado no direito europeu, entendendo tratar-se de manifestação do

${ }^{1}$ HESSE, Konrad. La fuerza normativa de la Constitución. In: Konrad Hesse. Escritos de Derecho Constitucional. Trad. Pedro Cruz Villalón. Madrid: Centro de Estudios Constitucionales, 1983.

${ }^{2}$ LASSALLE, Ferdinand. O que é uma Constituição? Belo Horizonte, MG: Líder, 2004. Cf. HESSE, Konrad. La fuerza normativa de la Constitución. In: Konrad Hesse.

Escritos de Derecho Constitucional. Trad. Pedro Cruz Villalón. Madrid: Centro de Estudios Constitucionales, 1983, p. 59-84.

${ }^{3}$ BARROSO, Luís Roberto. O Direito Constitucional e a Efetividade de suas Normas: limites e possibilidades da Constituição Brasileira. $6^{a}$ ed. Rio de Janeiro, RJ: Renovar, 2002, p. 89. 
princípio da confiança, amplamente reconhecido no direito da Europa continental. ${ }^{4}$

No Brasil, a discussão tem início na obra de José Afonso da Silva ${ }^{5}$, em sua já clássica tripartição das normas constitucionais em comandos de eficácia plena, contida e limitada. As primeiras seriam autoaplicáveis, já imediatamente prontas para produzir efeitos no mundo jurídico; as segundas seriam inicialmente autoaplicáveis, porém passíveis de conformação pelo legislador infraconstitucional; já as terceiras seriam apenas programáticas, dependendo da ação do legislador para serem implementadas. Contudo, mesmo as normas ditas programáticas já produziriam um efeito imediato, que independeria de sua regulamentação: a vedação à edição de normas infraconstitucionais que contrariassem os ditames dos comandos de eficácia limitada, i.e., a vedação ao retrocesso pelo legislador.

Com isso, restou reconhecida, pela primeira vez na tradição do direito constitucional brasileiro, a existência do princípio da vedação ao retrocesso, que, grosso modo, trata da proibição - ou, em sua versão mais contemporânea, dita fraca, da fixação de balizas - de edição de normas que representem uma menor proteção e/ou efetivação de direitos já reconhecidos e tutelados no ordenamento.

A proibição do retrocesso é, ademais, reconhecida como uma das quatro eficácias dos princípios enumeradas por Luís Roberto Barroso. ${ }^{6}$ Para o autor, os princípios possuem quatro eficácias: (i) jurídica positiva ou simétrica, que assegura o poder de enforcement da norma jurídica, seja ela veiculada por meio de uma regra ou de um princípio; (ii) interpretativa, segundo a qual as normais jurídicas devem ser interpretadas de acordo com os princípios constitucionais; (iii) negativa, que permite a invalidação de normas e atos contrários aos princípios jurídicos; e (iv) vedativa do retrocesso, que torna inadmissível a revogação de normas que concedam ou ampliem direitos fundamentais, sem que a modificação seja seguida de política substitutiva ou análoga.

${ }^{4}$ RUFFERT, Matthias (ed.). Administrative Law in Europe: between Common

Principles and National Traditions. Groningen: Europa Law Publishing, 2013. Ver também CANOTILHO, J.J. Gomes. Direito Constitucional e Teoria da Constituição. $4^{\mathrm{a}}$ ed. Coimbra: Almedina, 2000.

${ }^{5}$ SILVA, José Afonso da. Comentário Contextual à Constituição. 7ª ed. São Paulo, SP: Malheiros, 2010.

${ }^{6}$ BARROSO, Luís Roberto. Interpretação e Aplicação da Constituição: fundamentos de uma dogmática constitucional transformadora. $7^{a}$ ed. São Paulo, SP, RJ: Saraiva, 2009, p. 378-381. 
Há, ainda, autores de peso em defesa da existência do princípio da vedação do retrocesso, como Ana Paula de Barcellos ${ }^{7}$ Ingo Sarlet ${ }^{8}$ e Felipe Derbli ${ }^{9}$. Nesse sentido, correto afirmar que a proteção contra o retrocesso encontra guarida na doutrina brasileira majoritária.

Sendo assim, a incidência do princípio da proibição do retrocesso conduziria à invalidade de medidas que acarretassem compressões a direitos fundamentais mesmo que em contextos de combate a crises econômicas, uma vez que conquistas sociais fariam parte do avanço civilizatório do Estado Democrático de Direito, não podendo ser abandonadas mesmo em contextos de crise econômica severa.

\section{Princípio da Igualdade}

O segundo argumento contrário a restrições de direitos sociais seria o princípio da igualdade, tanto na sua vertente formal quanto na material, uma vez que as ações anti-crise frequentemente acabam por impor sacrifícios maiores apenas a grupos já anteriormente mais vulneráveis, como trabalhadores assalariados e aposentados (realidade que fica evidente já na análise das legislações europeias citadas na introdução).

A questão da violação à igualdade se mostra particularmente premente em Portugal, onde, em combate à crise financeira iniciada em 2008 , foram editadas diversas medidas que afetaram severamente grupos vulneráveis (como servidores públicos e aposentados), mas, por outro lado, não foi revisto nenhum contrato firmado com fornecedores e grandes agentes privados no âmbito de parcerias público-privadas. ${ }^{10}$

\footnotetext{
${ }^{7}$ BARCELLOS, Ana Paula de. A Eficácia Jurídica dos Princípios Constitucionais: o Princípio da Dignidade da Pessoa Humana. 2ª ed. Rio de Janeiro, RJ: Renovar, 2008, p. 86-88.

${ }^{8}$ SARLET, Ingo Wolfgang. Direito Fundamentais Sociais e Proibição do Retrocesso: algumas notas sobre o desafio da sobrevivência dos Direitos Sociais num contexto de Crise. Revista da Ajuris, Ano XXXI, No. 95, 2004.

${ }^{9}$ DERBLI, Felipe. O Princípio da Proibição do Retrocesso Social na Constituição de 1988. Rio de Janeiro, RJ: Renovar, 2007.

10 Vejamos os comentários de Jorge Bacelar Gouveia, Professor Catedrático da Faculdade de Direito da Universidade Nova de Lisboa e da Universidade Autónoma de Lisboa, sobre o tema: “Tem-se dito que não se pode reduzir as despesas do Estado em relação às parcerias público-privadas porque as parcerias público-privadas são fixas, ou são reguladas por um contrato, e a vontade contratual é sagrada, não se podendo alterar os contratos. (...) Depois também se tem pensado em introduzir um
} 
Especificamente no direito brasileiro, pode-se mencionar, ainda, o art. 5º, XXXVI da Constituição da República de 1988, segundo o qual "a lei não prejudicará o direito adquirido, o ato jurídico perfeito e a coisa julgada". Assim, não pareceria possível, na ordem constitucional pátria, a edição de medidas anti-crise (ao menos aquelas veiculadas por meio de lei em sentido estrito) que violem direitos adquiridos, atos jurídicos perfeitos nem coisa julgada. ${ }^{11}$

Os argumentos acima expostos não parecem, contudo, suficientes para afastar, de antemão, a possibilidade de formulação de medidas anticrise que produzam efeitos sobre direitos sociais, uma vez que se baseiam em ponderações de princípios que somente podem ser sopesados à luz do caso concreto, a depender do conteúdo da norma questionada. Entendemos que esses argumentos poderão apenas servir de base para um debate acerca da juridicidade de uma medida em específico, e não de qualquer ação governamental que imponha restrições a direitos sociais em momentos de grave recessão econômica.

corte geral de $20 \%$ na despesa pública com as PPPs. Mas logo se diz: 'Ah, mas isso não é possível, porque mesmo que se fizesse isso não se resolveria o problema da despesa pública', uma vez que a massa salarial - de facto, é verdade, do ponto de vista de despesa do Estado - corresponde a $2 / 3$ da despesa total. Mas mesmo que não resolvesse o problema, certamente essa regra o minoraria e, sobretudo, introduziria um tónus de justiça, de os cidadãos não ficarem a pensar que são os únicos culpados e que têm de suportar uma crise que deve ser repartida por todos, sejam trabalhadores ou não trabalhadores, sejam portugueses ou estrangeiros". GOUVEIA, Jorge Bacelar. Da Constituição da Crise à Crise da Constituição. In: Jorge Bacelar Gouveia e Nuno Piçarra (Orgs.). A Crise e o Direito. Coimbra: Almedina, 2013, p. 196-199.

${ }^{11}$ Para maiores considerações sobre o tema, vide SOUZA NETO, Cláudio Pereira de; SARMENTO, Daniel. Direito Constitucional: Teoria, História e Métodos de

Trabalho. $2^{\mathrm{a}}$ ed. Belo Horizonte: Fórum, 2014. Há, por exemplo, divergência na doutrina pátria quanto à possibilidade de emenda constitucional afetar direitos adquiridos. 


\section{Argumentos FAVOrÁveis a Restrições DE Direitos SOCIAIS EM MOMENTOS DE CRISE}

\section{A Reserva do Possível, o Núcleo Essencial de Direitos Fundamentais e o Mínimo Existencial}

A expressão reserva do possível (Vorbehalt des Möglichen) foi utilizada pela primeira vez pelo Tribunal Constitucional Federal Alemão, na decisão BVerfGE 33, de 18 de julho de 1972, na qual se entendeu pela constitucionalidade de normas de direito estadual que, em razão da limitação da oferta do número de vagas nos cursos superiores de medicina nas universidades de Hamburgo e da Baviera, regulamentavam o processo seletivo dos candidatos. No caso, entendeu o Tribunal ser possível restringir o acesso às faculdades de medicina, uma vez que os direitos sociais "se encontram sob a reserva do possível, no sentido de estabelecer o que pode o indivíduo, racionalmente falando, exigir da coletividade". ${ }^{12}$

Se, na Alemanha, a reserva do possível está atrelada àquilo que é razoável se exigir da sociedade, no Brasil, ela ganhou contornos ligados à disponibilidade de recursos orçamentários por parte do Estado. E o que podemos observar no seguinte trecho de Ana Paula de Barcellos: "a expressão reserva do possível procura identificar o fenômeno econômico da limitação dos recursos disponíveis diante das necessidades quase sempre infinitas a serem por eles supridas". ${ }^{13}$

A autora divide, ainda, a reserva do possível em fática e jurídica ${ }^{14}$, sendo a primeira ligada à efetiva existência de recursos públicos para realizar determinada ação e a segunda relacionada à previsão de recursos orçamentários para fazer frente àquela despesa. Eros Grau complementa o ponto afirmando que a reserva do possível fática existiria nos casos em que, assegurados os recursos indispensáveis à continuidade dos serviços

${ }^{12}$ FALSARELLA, Christiane. Reserva do Possível como aquilo que é razoável se exigir do Estado. Disponível em:

$<$ http://www.apesp.org.br/comunicados/images/tese christiane mina out2012.pdf $>$. Acesso em: 17 de outubro de 2017.

${ }^{13}$ BARCELLOS, Ana Paula de. A Eficácia Jurídica dos Princípios Constitucionais: o Princípio da Dignidade da Pessoa Humana. 3ª̣ ed. Rio de Janeiro, RJ: Renovar, 2011, p. 276.

${ }^{14}$ BARCELLOS, Ana Paula de. A Eficácia Jurídica dos Princípios Constitucionais: o Princípio da Dignidade da Pessoa Humana. 3ª ed. Rio de Janeiro, RJ: Renovar, 2011, p. 277-278.

3 JOURNAL OF INSTITUTIONAL STUDIES 2 (2017) 
públicos essenciais, não houver disponibilidade de caixa para a despesa pretendida..$^{15}$ Ingo Sarlet, por sua vez, entende que a reserva do possível teria dimensão tríplice, abarcando, além dos aspectos fático e jurídico, a razoabilidade e a proporcionalidade da prestação que se exige do poder público. ${ }^{16}$

Nesse sentido, em momentos de crise, a efetiva disponibilidade de recursos públicos em caixa tende a se mostrar reduzida, ante a diminuição da atividade produtiva (e, consequentemente, da arrecadação tributária) no país. Assim, o argumento da reserva do possível fática torna-se um importante instrumento para a edição de medidas de combate a crises que possam restringir de alguma forma direitos sociais.

Todavia, essa compressão não poderá atingir o mínimo existencial, tendo em vista o consenso ${ }^{17}$ de que a reserva do possível não pode servir

${ }^{15}$ GRAU, Eros. A Emenda Constitucional no 30/00: pagamento de precatórios judiciais.

Revista de Direito Administrativo, No. 229, 2002; e BARCELLOS, Ana Paula de. A Eficácia Jurídica dos Princípios Constitucionais: o Princípio da Dignidade da Pessoa Humana. $3^{\underline{a}}$ ed. Rio de Janeiro, RJ: Renovar, 2011, p. 278.

${ }^{16}$ Cf. SARLET, Ingo Wolfgang; FIGUEIREDO, Mariana Filchtiner. Reserva do Possível, Mínimo Existencial e Direito à Saúde: algumas aproximações. Revista de Doutrina da $4^{\mathrm{a}}$ Região, No. 24, 2008. Disponível em:

$<$ http://www.revistadoutrina.trf4.jus.br/index.htm?http://www.revistadoutrina.trf4.jus. br/artigos/edicao024/ingo mariana.html>. Acesso em: 04 de fevereiro de 2018.

Contudo, a ideia de reserva do possível fática não é imune a críticas, como se pode observar nas palavras de Ricardo Lobo Torres: "possibilidade de adjudicação de direitos prestacionais se houver disponibilidade financeira, que pode compreender a existência de dinheiro sonante na caixa do Tesouro, ainda que destinado a outras dotações orçamentárias! Como o dinheiro público é inesgotável, pois o Estado sempre pode extrair mais recursos da sociedade, segue-se que há permanente possibilidade fática de garantia de direitos, inclusive na via do sequestro da renda pública! Em outras palavras, faticamente é impossível a tal reserva do possível fática". TORRES, Ricardo Lobo. O Direito ao Mínimo Existencial. Rio de Janeiro, RJ: Renovar, 2009, p. 110 .

${ }^{17}$ Nesse sentido, BARCELLOS, Ana Paula de. A Eficácia Jurídica dos Princípios Constitucionais: o Princípio da Dignidade da Pessoa Humana. $3^{\underline{a}}$ ed. Rio de Janeiro, RJ: Renovar, 2011, p. 287-288; SARLET, Ingo Wolfgang; FIGUEIREDO, Mariana Filchtiner. Reserva do Possível, Mínimo Existencial e Direito à Saúde: algumas aproximações. Revista de Doutrina da $4^{a}$ Região, No. 24, 2008, p. 36. Disponível em: $<$ http://www.revistadoutrina.trf4.jus.br/index.htm?http://www.revistadoutrina.trf4.jus. br/artigos/edicao024/ingo mariana.html >. Acesso em: 04 de fevereiro de 2018; e 
de argumento para a não realização do mínimo existencial - muito embora seja dura a tarefa de identificar seu conteúdo.

Para Ana Paula de Barcellos, por exemplo, o mínimo existencial é composto por educação fundamental (ensino fundamental, com prestações que assegurem condições de real aproveitamento para o aluno), saúde básica (que atenda às prioridades constitucionalmente estabelecidas para o setor, a saber, prestação de serviços de saneamento, atendimento materno-infantil, medicina preventiva e prevenção epidemiológica), assistência aos desamparados (alimentação, vestuário e abrigo) e acesso à justiça (jurídico, físico e da pretensão material). ${ }^{18}$

Do ponto de vista dos direitos sociais, entendemos que a educação intermediária (ensino médio) e técnica deve ser inserida no bojo do mínimo existencial. A medida é salutar para permitir que cada indivíduo possa realizar seu projeto pessoal de vida boa, pilar da teoria de justiça elaborada por Ronald Dworkin ${ }^{19}$, tendo em vista que a instrução é requisito fundamental para a escolha da profissão, para o exercício de liberdade individuais (liberdade dos modernos) e para a participação no debate político (liberdade dos antigos).

Em segundo lugar, consideramos que a garantia dos direitos fundamentais de primeira geração (tais como a liberdade de expressão, de religião e de pensamento), ligados ao exercício das liberdades individuais deve, também, integrar o mínimo existencial, uma vez que, sem estas, não se mostra possível a realização de projetos pessoais de vida boa.

Dessa forma, ainda que se admita a restrição de direitos sociais em momentos de crise severa, essa compressão não poderá afetar o mínimo existencial - que, para nós, é composto de liberdades fundamentais e direitos sociais à educação básica, média e técnica, saúde básica e assistência aos desamparados -, sob pena de violação frontal à dignidade

CANOTILHO, J.J. Gomes. Direito Constitucional e Teoria da Constituição. $4^{\mathrm{a}}$ ed. Coimbra: Almedina, 2000, p. 481.

${ }^{18}$ BARCELLOS, Ana Paula de. A Eficácia Jurídica dos Princípios Constitucionais: o Princípio da Dignidade da Pessoa Humana. $2^{\underline{a}}$ ed. Rio de Janeiro, RJ: Renovar, 2008, p. 277-333.

${ }^{19}$ Nas palavras do próprio autor, "nenhum governo é legítimo a menos que endosse dois princípios soberanos. Em primeiro lugar, ele deve demonstrar igual consideração pelo destino de toda pessoa sobre a qual pretende ter domínio. Em segundo lugar, deve respeitar plenamente a responsabilidade e o direito de toda pessoa de decidir por si mesma como fazer de sua vida algo valioso". DWORKIN, Ronald. A Raposa e o Porco-Espinho: Justiça e Valor. Trad. de Marcelo Brandão Cipolla. São Paulo, SP: WMF Martins Fontes, 2014, p. 4-5. 
da pessoa humana, na sua vertente do valor intrínseco de cada ser humano. ${ }^{20}$

\section{As versões fracas do Princípio da Proteção à Confiança Legítima e da Proteção ao Direito Adquirido}

Seguindo adiante na argumentação favorável à maior plasticidade dos direitos sociais em momentos de crise, mesmo a proibição do retrocesso pode embasar as ideias ora defendidas, na medida em que, como já ensinou J.J. Gomes Canotilho, este princípio, na sua formulação fraca, recai apenas sobre o núcleo essencial de direitos fundamentais. ${ }^{21}$

${ }^{20}$ Luís Roberto Barroso propõe a decomposição da dignidade da pessoa humana nos seguintes aspectos: "valor intrínseco da pessoa humana, autonomia da vontade e valor comunitário. $\mathrm{O}$ valor intrínseco da pessoa humana está profundamente ligado às raízes do pensamento kantiano, segundo qual toda pessoa é merecedora de igual respeito e consideração. Para Kant, as coisas têm preço, os seres humanos possuem dignidade. Já a autonomia da vontade subdividir-se-ia em: a) autodeterminação, isto é, o direito do indivíduo de decidir os rumos da própria vida e desenvolver livremente sua personalidade; b) autonomia privada (ou liberdade dos modernos), ligada aos direitos individuais, e autonomia pública (ou liberdade dos antigos), relacionada aos direitos políticos; e c) mínimo existencial, ou seja, direito a determinadas prestações e utilidades elementares, necessárias para que toda pessoa seja verdadeiramente livre, igual e capaz de exercer sua cidadania; constitui o núcleo essencial dos direitos fundamentais em geral e seu conteúdo corresponde às pré-condições para o exercício dos direitos individuais e políticos, da autonomia pública e privada. Por sua vez, o valor comunitário traduz uma concepção ligada a valores compartilhados pela comunidade, segundo padrões civilizatórios ou seus ideais de vida boa, assim como às responsabilidades e aos deveres de cada um, funcionando como limite às escolhas individuais. Nesse ponto, a fim de minimizar o risco de paternalismo ou ditadura da maioria, Barroso defende que devem ser levados em consideração nos casos concretos (a) a existência ou não de direito fundamental em jogo, (b) a existência de consenso social forte em relação à questão e (c) a existência de risco efetivo para direitos de terceiros". BARROSO, Luís Roberto. A Dignidade da Pessoa Humana no Direito Constitucional Contemporâneo: natureza jurídica, conteúdos mínimos e critérios de aplicação. Interesse Público, Vol. 14, 76, 2012.

${ }^{21}$ CANOTILHO, J.J. Gomes. Direito Constitucional e Teoria da Constituição. $4^{\underline{a}}$ ed. Coimbra: Almedina, 2000, p. 333.

3 JOURNAL OF INSTITUTIONAL STUDIES 2 (2017) 
Dessa forma, observa-se que medidas anti-crise que não representem violação ao chamado núcleo duro de direitos fundamentais poderão ser adotadas sem que haja qualquer mácula à sua constitucionalidade. Assim como no mínimo existencial, a definição do núcleo essencial de direitos fundamentais comporta dificuldades práticas, dado o caráter etéreo do conceito, de modo que os limites desse núcleo duro deverão ser delineados à luz do caso concreto. ${ }^{22}$

Ademais, a vedação ao retrocesso é, no direito europeu, princípio que deriva da proteção da confiança, a qual, por sua vez, pode ser enxergada sob uma formulação mais fraca, de que a confiança legítima somente se justifica caso mantido o mesmo contexto fático em que a norma anterior fora editada; alterando-se este cenário, não poderia o destinatário da norma anterior esperar legitimamente sua manutenção.

A versão fraca do princípio da confiança pode ser perfeitamente aplicada a situações de crise. E o que ensina António Manuel Hespanha:

\begin{abstract}
Num contexto de crise, o princípio da confiança favorece a manutenção do direito e das soluções jurídicas anteriores à crise, pois seria nessa base que as pessoas tinham definido os conteúdos e consequências das situações jurídicas em que estavam. Na formulação mais fraca, as expectativas têm por base a manutenção do contexto, mas já não a sua alteração anormal e imprevisível, pelo que, ocorrendo uma alteração extraordinária das circunstâncias, a alteração da solução jurídica não ofenderá essas expectativas. Tal alteração corresponderá até a uma das formulações do princípio (versão mutatis mutandis): uma alteração (grave e não previsível) das circunstâncias provoca uma alteração da solução. 23
\end{abstract}

A concretização dos princípios constitucionais não é absoluta, devendo se encontrar um arranjo possível entre as demandas existentes, os ditames de outros princípios e, ainda, a realidade da época. Nas palavras de Barroso:

22 Para maiores considerações sobre o núcleo essencial de direitos fundamentais, vide: BARCELLOS, Ana Paula de. A Eficácia Jurídica dos Princípios Constitucionais: o Princípio da Dignidade da Pessoa Humana. $3^{a}$ ed. Rio de Janeiro, RJ: Renovar, 2011. ${ }^{23}$ HESPANHA, António Manuel. A revolução neoliberal e a subversão do "modelo jurídico": crise, direito e argumentação jurídica. In: Jorge Bacelar Gouveia e Nuno Piçarra (Orgs.). A Crise e o Direito. Coimbra: Almedina, 2013, p. 93-94. 
A efetividade da Constituição há de se assentar sobre alguns pressupostos indispensáveis. É preciso que haja, da parte do Constituinte, senso de realidade, para que não pretenda normatizar o inalcançável, o que seja materialmente impossível em dado momento e lugar. ${ }^{24}$

Em momentos de crise econômica severa, naturalmente a realidade se mostra bastante distinta do que em momentos de expansão econômica, com uma disponibilidade de recursos orçamentários muito mais limitada do que em períodos de normalidade. Esse estado de coisas acabará por influir nas possibilidades reais de implementação e expansão de políticas públicas, levando a um encolhimento do Estado Social. Com isso, revelase a necessidade do desenvolvimento de uma teoria jurídica que comporte compressões razoáveis - desde que necessárias - a direitos sociais, "já que o direito positivo estabelecido, que é pensado para a estabilidade do normal, seria insuficiente e inadequado para as situações extraordinárias". ${ }^{25}$

Ademais, o senso de realidade pode ser, igualmente, identificado com a busca pela sinceridade normativa e com a reserva do possível fática, expressão ligada àquilo que, diante da limitação dos recursos públicos, se é efetivamente possível exigir do Estado na concretização de direitos sociais.

Por essa visão mais contemporânea da proteção aos direitos adquiridos, seria possível que, em momentos de considerável crise, haja uma relativização do amparo a direitos já adquiridos, desde que permeada por um cotejo entre razoabilidade da medida restritiva e a legitimidade (chamada por Barroso de relevância) da expectativa do beneficiário daquela situação jurídica de que ela será mantida.

No direito brasileiro em particular, a jurisprudência é assente quanto à inexistência de direito adquirido a regime jurídico de servidores

${ }^{24}$ BARROSO, Luís Roberto. A Doutrina Brasileira da Efetividade. Temas de Direito Constitucional. Tomo III. Rio de Janeiro, RJ: Renovar, 2005, p. 71.

${ }^{25}$ HESPANHA, António Manuel. A revolução neoliberal e a subversão do "modelo jurídico": crise, direito e argumentação jurídica. In: Jorge Bacelar Gouveia e Nuno Piçarra (Orgs.). A Crise e o Direito. Coimbra: Almedina, 2013, p. 100. 
públicos ${ }^{26}$, ainda que se reconheça a irredutibilidade de remuneração como garantia constitucional aplicável aos agentes públicos. ${ }^{27}$

O ponto é bastante relevante para contextos de crise econômica, na medida em que, como visto, os gastos com pessoal representam parcela considerável das despesas públicas (em Portugal, por exemplo, atingem $2 / 3$ dos gastos do governo). Assim, muito embora não seja possível a redução nominal dos vencimentos dos servidores (nem, tampouco, a redução do valor pago pela hora de trabalho ${ }^{28}$ ), o ordenamento pátrio admite mudanças no regime jurídico de servidores públicos (critérios para o cálculo de aposentadorias e pensões, por exemplo ${ }^{29}$ ), o que pode representar espaço para medidas de combate à crise. ${ }^{30}$

\section{Pragmatismo Jurídico e Consequencialismo}

As compressões a direitos sociais em contextos de crise econômica podem ser, finalmente, justificadas sob as luzes do pragmatismo jurídico, sob o argumento inexorável da necessidade fática: nas palavras do Ministro da Economia português, "não há dinheiro". ${ }^{31}$ Como sintetiza

${ }^{26}$ Por todos, cite-se STF. AgR-RE 227.755/CE, Min. Rel. Dias Toffoli. Primeira Turma, Publicado em 02/10/2012.

${ }^{27}$ Vide STF, ED-MS 31.353/DF, Min. Rel. Rosa Weber, Primeira Turma, Pulicado em 07/04/2015.

${ }^{28}$ É possível transformar o regime de um servidor de jornada parcial em trabalho em tempo integral, já que não há direito adquirido a regime jurídico. Porém, a alteração deverá ser acompanhada do aumento proporcional da remuneração do servidor público, a fim de que não haja uma redução do seu salário/hora.

${ }^{29}$ Vide STF, ADI 3.105/DF. Min. Rel. Ellen Gracie. Red. p/ Acórdão Min. Cezar Peluso, Tribunal Pleno, Publicado em 18/08/2004.

${ }^{30}$ Não estamos, aqui, emitindo juízo de valor sobre a jurisprudência do Supremo Tribunal Federal sobre a inexistência de direito adquirido a regime jurídico de servidores públicos. Por ora, adotamos uma perspectiva meramente descritiva desse posicionamento jurisprudencial, destacando sua utilidade prática no combate a crises financeiras. Nossa visão aqui é, portanto, ontológica (e não deontológica).

${ }^{31} \mathrm{Na}$ época da crise de 2008, a situação das contas públicas chegou a níveis tão alarmantes que o Ministro da Economia, Vítor Gaspar, respondendo a questionamento de membro do Parlamento ao expor o pacote de medidas de arrocho que seria lançado nos idos de 2012, simplesmente afirmou: “Não há dinheiro. Qual das três palavras é que não percebeu?" Disponível em: $<$ http://www.cmjornal.xl.pt/opiniao/detalhe/naoha-dinheiro.html> Acesso em: 17 de outubro de 2017. A fala, porém, não foi imune a 
Jorge Bacelar Gouveia, "simplesmente, a crise existe e a Constituição não pode deixar de resolver esse problema. Então como é que esse problema pode ser resolvido" 32

É certo que a realidade fática é fruto de um contexto e de uma trajetória que se desenharam ao longo do tempo, de modo que a escassez de recursos verificada no presente amiúde tem origem em escolhas e decisões pretéritas em relação a investimentos e despesas de longo prazo. Por outro lado, não se pode ignorar que, independente da origem da falta de recursos atual, essa realidade inviabiliza a continuidade de políticas públicas até então desenvolvidas, demandando seu redimensionamento.

As escolhas pretéritas que tenham contribuído para o quadro de insuficiência financeira devem ser objeto de análise - e eventual responsabilização - próprias, seja em sede do processo eleitoral democrático, com a rejeição nas urnas do governo da época (a chamada accountability vertical ${ }^{33}$ ), seja em sede de responsabilidade jurídica, se verificado que a situação econômica não é fruto apenas de uma conjuntura desfavorável, mas, sim, de inobservância de norma jurídica atinente à responsabilidade fiscal. Aqui, porém, pretendemos analisar em que medida a realidade posta pode servir de fundamento, à luz do pragmatismo jurídico ${ }^{34}$, para a validação de certas restrições a direitos sociais, desde que reste preservado o mínimo existencial.

críticas. Disponível em: <http://gazetadabeira.pt/m-guimaraes-da-rocha-ed-669/> Acesso em: 17 de outubro de 2017.

32 HESPANHA, António Manuel. A revolução neoliberal e a subversão do "modelo jurídico": crise, direito e argumentação jurídica. In: Jorge Bacelar Gouveia e Nuno Piçarra (Orgs.). A Crise e o Direito. Coimbra: Almedina, 2013, p. 191.

${ }^{33}$ Para Guillermo O'Donnell, a accountability horizontal diz respeito à "existência de instituições estatais que tenham o direito e o poder legal, e estejam de fato dispostas e capacitadas para adotar medidas, que podem ir desde a supervisão de rotina à aplicação de sanções legais ou até o desfazimento de ações ou omissões de outras instituições estatais que possam ser qualificadas como ilícitas". O'DONNELL, Guillermo. Dissonances: Democratic Critiques of Democracy. Notre Dame: University of Notre Dame Press, 2007, p. 60 (tradução livre).

${ }^{34} \mathrm{O}$ pragmatismo jurídico surge no século $\mathrm{XX}$ a partir do movimento norteamericano do realismo jurídico, tendo como três características principais o contextualismo, o consequencialismo e o antifundacionalismo. $\mathrm{O}$ contextualismo prega que as medidas jurídicas levadas a cabo devem ser analisadas a partir de sua conformidade com as necessidades humanas e sociais daquele momento. O consequencialismo, por sua vez, requer que as proposições jurídicas sejam testadas por meio da antecipação de suas possíveis consequências. Por fim, o antifundacionalismo consiste na rejeição de 
O direito se encontra inserido no mundo dos fatos; não é possível o estudo jurídico de forma hermética, sem qualquer espaço para a penetração de outras áreas do conhecimento humano, tais como a sociologia, a antropologia e a economia. A aplicação do direito se dá dentro de um contexto mais amplo e a preocupação com as implicações das medidas a serem tomadas parece ser essencial para que a norma atinja a finalidade pretendida. $O$ pragmatismo reconhece esse contextualismo do direito, permitindo sua permeabilidade com outros elementos para além dele próprio e, com isso, admite sua mutabilidade diante das necessidades impostas pelas circunstâncias..$^{35}$

Em momentos de crise econômica severa, a imperiosidade de contenção de gastos pode levar a uma espécie de estado de necessidade pública, em que - para além de eventuais questionamentos em relação à origem e às causas desse estado - a adoção de medidas de austeridade que imponham restrições a direitos sociais seja simplesmente uma necessidade inexorável, tal qual ocorreu no momento da edição das Leis Orçamentárias Portuguesas de 2011 e 2012, no auge da crise iniciada em 2008.

No mesmo sentido, afirma Paulo Otero:

fundamentos metafísicos, conceitos abstratos, categorias apriorísticas, transcendentais e dogmáticas como base para a ação do direito. POSNER, Richard. Law, Pragmatism and Democracy. Cambridge, MA: Harvard University Press, 2005, p. 59-85. Ver também: POSNER, Richard. The Problems of Jurisprudence. Cambridge, MA: Harvard University Press, 1993, p. 454-469.

${ }^{35}$ Nas palavras de Thomas F. Cotter, "Although writers have defined ‘legal pragmatism' in various ways, probably the one fundamental concept on which all legal pragmatists agree is that knowledge, thought, and inquiry are simultaneously 'contextual' (or 'situated' or 'social') and 'instrumental'. (...) Pragmatism is valuable precisely because it destroys the illusion of objectivity in legal decisionmaking. Michael Seigel has argued, for example, that it can be liberating, even empowering, to recognize that our norms of decisionmaking are historically and culturally contingent; if law is nothing more than a human construct, then we can change those norms to suit our changing needs". COOTER, Thomas F. Legal Pragmatism and the Law and Economics Movement. Georgetown Law Journal, Vol. 84, 6, 1996, p. 2075-2080. Por outro lado, a visão pragmatista e a preocupação com as consequências das decisões não podem acarretar um completo vilipêndio ao Estado Democrático de Direito a suas conquistas. O discurso pragmático deve ser incorporado à tônica jurídica como um dos argumentos a serem levados em consideração quando da edição de medidas jurídicas, mas não pode ser o único deles. Nem o pragmatismo nem o consequencialismo poderiam funcionalizar vidas humanas ao ponto de suplantar a dignidade da pessoa humana. 
A necessidade financeira, numa situação de emergência, passou a ditar a lei fundamental do país, envolvendo a execução interna do Memorando do Acordo com a Troika, cenário em que o próprio Tribunal Constitucional sanciona a excecionalidade de medidas, qualificadas de transitórias ou até permitindo que atos inconstitucionais continuam a produzir efeitos depois da sentença que os declara inválidos, tudo num ambiente de verdadeira indiferença pela 'Constituição oficial' ou escrita. ${ }^{36}$

$\mathrm{O}$ argumento de cunho pragmático-consequencialista da necessidade pública, durante uma crise econômica, pode servir de fundamento à edição de medidas restritivas a direitos sociais que tenham por objetivo combater os efeitos da recessão.

Não obstante, este mesmo discurso não pode servir de fundamento para violações ao núcleo essencial de direitos fundamentais nem ao mínimo existencial, uma vez que a dignidade da pessoa humana não admite posições utilitaristas que desconsiderem o valor intrínseco de cada pessoa.

É dizer: o argumento pragmatista não deve ser considerado suficiente para legitimar medidas que atinjam o mínimo existencial, o qual se encontra umbilicalmente ligado à dignidade da pessoa humana. Medidas que comprometam este mínimo devem ser consideradas como antijurídicas, passíveis de invalidação administrativa (no exercício da autotutela) ou judicial, à luz do princípio da inafastabilidade do controle judicial, e, ainda, de responsabilização do agente público e da pessoa de direito público nos casos em que estejam presentes os elementos caraterizadores da responsabilidade civil e administrativa, como passaremos a desenvolver a seguir.

\section{AS MEDIDAS ANTI-CRISE COMO BURACOS NEGROS OU}

${ }^{36}$ OTERO, Paulo. A crise: um novo direito administrativo? In: Jorge Bacelar Gouveia e Nuno Piçarra (Orgs.). A Crise e o Direito. Coimbra: Almedina, 2013, p. 207-208. 


\section{Cinzentos}

A teoria das situações de crise - não propriamente as econômicas, mas principalmente aquelas que envolvam questões de segurança nacional como buracos negros (black holes) ou cinzentos (grey holes) é desenvolvida no direito norte-americano por autores como Adrian Vermeule ${ }^{37}$, Bruce Ackerman $^{38}$ e David Dyzenhaus ${ }^{39}$ no contexto histórico das respostas do governo George W. Bush aos atentados terroristas de 11/09/2001.

O ponto de partida dos autores é a crítica de Carl Schmitt, jurista alemão publicamente conhecido por seu apoio ao Nazismo, à República de Weimar, sustentando que a pretensão democrática de submeter a atuação do Estado a preceitos jurídicos e ao due process of law inexoravelmente esbarraria nas situações emergenciais e excepcionais.

Sustenta Dyzenhaus:

Os estados de emergência são um vazio normativo, um buraco negro jurídico em que o Estado age sem as constrições do direito. Já os buracos cinzentos seriam 'espaços jurídicos em que há algumas constrições à atuação administrativa - não se trata de um vácuo normativo - mas os limites são tão abertos que, na prática, permitem que o governo faça o que bem entender. ${ }^{40}$

Justamente para evitar o vácuo normativo gerado pelos buracos negros e cinzentos, Ackerman, por sua vez, traz a proposição da criação de uma Constituição da Emergência, dispositivos constitucionais que disciplinem situações de urgência delicada, os quais devem

37 VERMEULE, Adrian. Our Schmittian Administrative Law. Harvard Law Review, Vol. 122, 4, 2009, p. 1095.

${ }^{38}$ ACKERMAN, Bruce. The Emergency Constitution. Yale Law Journal, Vol. 113, 5, 2004.

${ }^{39}$ DYZENHAUS, David. Schmitt v. Dicey: Are States of Emergency Inside or Outside the Legal Order? Cardozo Law Review, Vol. 27, 5, 2006.

${ }^{40}$ No original: "A state of emergency is a lawless void, a legal black hole, in which the State acts unconstrained by law. A grey hole is a legal space in which there are some legal constraints on executive action - it is not a lawless void - but the constraints are so insubstantial that they pretty well permit government to do as it pleases".

DYZENHAUS, David. Schmitt v. Dicey: Are States of Emergency Inside or Outside the Legal Order? Cardozo Law Review, Vol. 27, 5, 2006, p. 2018. 
necessariamente contemplar os seguintes pontos: (i) necessidade de referendo do estado de emergência pelo Legislativo; (ii) compartilhamento de informações de inteligência envolvendo segurança nacional com comissões formadas pelo Legislativo, nas quais a maioria dos assentos seria reservada aos partidos de oposição; e (iii) possibilidade de o Judiciário assegurar o cumprimento das regras da Constituição da Emergência (macropapel) e controlar as prisões e detenções sumárias de suspeitos (micropapel), vedada a tortura desses detentos.

Dyzenhaus afirma que a proposta ackermaniana, ainda que tenha o mérito de reconhecer os perigos dos grey holes, não os soluciona por completo, uma vez que ainda trabalha com conceitos jurídicos indeterminados e não leva em considerações situações em que a própria Constituição da Emergência precisasse ser suspensa. O autor alerta para os perigos dos buracos cinzentos, apontando que eles "conferem um verniz de legalidade à supressão oficial do Estado Democrático de Direito". ${ }^{41}$

Vermeule diverge de Dyzenhaus ao sustentar que os buracos cinzentos são intrinsecamente parte da tradição jurídica norteamericana, trazendo uma série de exemplos para ilustrar seu argumento, tais como a possibilidade de revisão judicial de atos administrativos "arbitários ou caprichosos" (U.S. Code, §706) e a não submissão da Presidência da República ao Administrative Procedure Act ( $A P A$ ), tendo em vista seu não enquadramento no conceito de agência trazido pela própria lei, como assentado nos precedentes Dalton $v$. Specter (1994) e Franklin $v$. Massachussetts (1992). ${ }^{42}$

Mais do que isso: Vermeule defende que os buracos negros e cinzentos seriam necessários ao direito administrativo, haja vista não só a imprevisibilidade e a complexidade das situações concretas com que este deverá lidar, sobretudo em contextos de anormalidade institucional, como também a onipresença dos conceitos jurídicos indeterminados na ordem jurídica em geral.

A teoria dos buracos negros e cinzentos foi desenvolvida, reitere-se, para emergências de segurança nacional. Vermeule, em nota de rodapé, afirma expressamente que seu foco está "no período pós 11/09 e nas emergências relativas à segurança nacional, e não nas de ordem

${ }^{41}$ No original: "The real test for his challenge is whether legislative responses to emergencies necessarily create black holes or grey holes which are in substance black but, as we have seen, in effect worse because they give to official lawlessness the façade of legality". DYZENHAUS, David. Schmitt v. Dicey: Are States of Emergency Inside or Outside the Legal Order? Cardozo Law Review, Vol. 27, 5, 2006, p. 2039. ${ }^{42}$ Cf. Dalton v. Specter, 511 U.S. 462 (1994); e Franklin v. Massachusetts, 505 U.S. 788, 802 (1992). 
econômica ou advindas de desastres naturais ou mudanças climáticas". ${ }^{43}$ Reconhece o autor, porém, que muitas - embora não todas - de suas observações sejam também aplicáveis a essas outas espécies de crises, inclusive as econômicas, objeto do presente estudo. Posteriormente, o próprio Vermeule, em artigo escrito conjuntamente com Eric Posner, trata dos buracos negros e cinzentos ao comparar as situações vivenciadas nos EUA pós $11 / 09$ e durante a crise de 2008.4

Em artigo específico sobre emergências econômicas, Bernadette Meyler, na mesma linha de Vermeule, aponta para a necessidade de existência de espaços de conformação que permitam a intervenção do governo na economia, ainda que essa atuação possa temporariamente desestabilizar a lógica do livre mercado, desde que não afete liberdades individuais e os direitos políticos dos cidadãos. A própria autora adverte, contudo, que não tem a pretensão de prescrever ações interventivas estatais, mas apenas de reconhecer a existência desse espaço democrático de deliberação quanto às liberdades econômicas, contanto que observados os direitos básicos dos indivíduos, como o habeas corpus e o voto. 45

Nesse sentido, a existência dos buracos cinzentos parece-nos inevitável para garantir margem de conformação ao projeto social em curso, mas, para evitar arbitrariedades, esses espaços devem ser passíveis

${ }^{43}$ No original: "By 'administrative law', I mean the administrative law of the federal government of the United States. I focus on the post-9/11 period and on emergencies implicating national security, rather than on economic emergencies or on emergencies arising from natural disasters or environmental change. (By 'emergencies', then, I mean security emergencies unless otherwise specified.) Many of the points I will make apply in those other settings as well, although some do not." VERMEULE, Our Schmittian Administrative Law. Harvard Law Review, Vol. 122, 4, 2009, p. 1095-1096. ${ }_{44}$ POSNER, Eric; VERMEULE, Adrian. Crisis Governance in the Administrative State: 9/11 and the Financial Meltdown of 2008. University of Chicago Law Review, Vol. 76, 4, 2009.

${ }^{45}$ No original: "This Article contends that, in the United States context, the rule of law should be conceived flexibly enough to permit governmental intervention that may temporarily disrupt the economic but not personal liberty or political participation rights of individuals during these situations of economic emergency. Without addressing whether and to what extent the government should interfere in the economic sphere, this Article argues that several justifications based in the democratic vision underlying our constitutional system warrant treating the suspension of economic rights differently from the suspension of rights such as those of habeas corpus or the vote". MEYLER, Bernadette. Economic Emergency and the Rule of Law. De Paul Law Review, Vol. 56, 2, 2007. 
de controle pelo Judiciário, o qual, após um juízo de estrito escrutínio, poderá invalidar medidas que se mostrem violadoras de direitos fundamentais. Os buracos negros, por sua vez, não parecem compatíveis com a ordem constitucional brasileira, que, como visto, consagra o princípio da inafastabilidade da apreciação de lesões e ameaças de lesões a direitos pelo Poder Judiciário.

No Brasil, Marcelo Valença Ramos ${ }^{46}$ defende que a teoria dos buracos negros e cinzentos pode ser utilizada no âmbito de ações de enfrentamento a crises econômicas, dando como exemplo a decisão do Supremo Tribunal Federal no já histórico julgamento da ADI no 534, ajuizada pelo Partido Socialista Brasileiro em face da Medida Provisória $\mathrm{n}^{\mathrm{o}} 168$, posteriormente convertida na Lei $\mathrm{n}^{\mathrm{o}}$ 8.024/1990, que criava o Plano Collor.

O plano econômico em questão promoveu o congelamento, pelo período de 18 meses, de $80 \%$ dos depósitos bancários e investimentos de pessoas físicas e jurídicas em ativos financeiros superiores a cinquenta mil cruzados novos. Na ocasião, o STF, por maioria, indeferiu a Medida Cautelar requerida, entendendo que não haveria periculum in mora na manutenção do plano, tendo em vista tratar-se de congelamento temporário. No mérito, o Requerente alegava que a medida representava um empréstimo compulsório disfarçado, desrespeitando os ditames do art. 148 da Constituição Federal, que exige a edição de lei complementar para instituição dessa espécie tributária. A ação acabou por perder o objeto pelo decurso do prazo para o congelamento, não tendo seu mérito analisado.

De acordo com Ramos, a utilização de conceitos jurídicos indeterminados, como interesse público e periculum in mora, para permitir a manutenção de uma polêmica medida do Executivo em combate a uma severa crise econômica funcionaria como um buraco cinzento, trazendo os típicos elementos deste instituto, como o consequencialismo e o reconhecimento de uma assimetria de informação entre o Judiciário e o Executivo no que tange à formulação de políticas econômicas, o que demandaria uma maior deferência à opção administrativa. ${ }^{47}$

${ }^{46}$ RAMOS, Marcelo Valença. Releitura sistêmico-teórica das relações entre direito, política e economia: a crise de $\mathbf{2 0 0 8}$ como ponto de inflexão para a emergência do constitucionalismo societal. 190 f. 2014. Dissertação (Mestrado em Direito), Programa de Pós-Graduação em Direito da Universidade Estadual do Rio de Janeiro, Universidade Estadual do Rio de Janeiro, Rio de Janeiro, RJ, 2014, p. 163.

${ }^{47}$ No caso em questão, a grave crise econômica causada pela hiperinflação e possivelmente alguns outros fatores circunstanciais levaram o STF a utilizar conceitos indeterminados e ajustáveis para evitar ter que aferir a constitucionalidade do Plano 
Nesta ordem de ideias, o reconhecimento das medidas anti-crise como um buraco cinzento evidencia a existência de um espaço de conformação do gestor à luz da realidade que se apresenta, em sintonia com os ditames do pragmatismo jurídico. Ademais, faz com que essas ações sejam consideradas uma zona de maior deferência dos órgãos de controle às ações administrativas, haja vista a maior expertise técnica do Executivo em assuntos financeiros e da maior capacidade deste Poder de formular uma macrovisão sobre o orçamento público, instando maior autocontenção aos órgãos de controle.

\section{Viabilidade JURÍdicA DE RESTRIÇÕES FRACAS A DiREITOS SOCIAIS POR MEDIDAS ANTI-CRISE ECONÔMICA E MECANISMOS DE CONTROLE DESSAS RESTRIÇÕES}

Como visto, restrições a direitos sociais em períodos de crise econômica severa encontram um limitador importante: o núcleo essencial dos direitos fundamentais e o mínimo existencial - que, para nós, é composto de liberdades fundamentais e direitos sociais à educação básica, média e técnica, saúde básica e assistência aos desamparados -, os quais não poderão ser atingidos pelas medidas anti-crise, uma vez que salvaguardam o núcleo duro da dignidade da pessoa humana, fundamento último do Estado Democrático de Direito.

$\mathrm{O}$ reconhecimento desses limites faz com que as ações de combate a crises econômicas deixem de ser um buraco negro, oferecendo parâmetros para a definição de sua juridicidade. Deve-se entender, assim, pela juridicidade de medidas que, dentro das limitações impostas pelo

Collor, convenientemente aguardando o fim do prazo de 18 meses para então declarar a ADIn prejudicada. Trata-se, portanto, de buracos cinzentos utilizados não apenas pelo Poder Judiciário, mas também pelo Legislativo (que aprovou a conversão da Medida Provisória no 168 na Lei no 8.024/1990), para permitir que o Poder Executivo promulgasse e se valesse de norma possivelmente inconstitucional no combate à crise de hiperinflação. É ilustrativo nesse sentido o voto do Min. Ilmar Galvão, que curiosamente inverteu a análise do periculum in mora no julgamento da Medida Cautelar. Estão presentes no referido voto (a) o reconhecimento de déficit informacional em relação ao Poder Executivo; (b) o temor de riscos e consequências adversas associados à tomada de decisões relacionadas a questões econômicas complexas e (c) a utilização de conceitos indetermináveis e ajustáveis (interesse público e periculum in mora) como válvulas de escape para situações de crise. 
núcleo duro dos direitos humanos e pelo mínimo existencial, imponham restrições fracas a direitos sociais em momentos de crise econômica severa.

Nessa versão leve, a crise funcionará como um vetor interpretativo a respeito da juridicidade das medidas adotadas pelo poder público no exercício de suas atribuições democráticas, admitindo-se, à luz da realidade fática que recai sobre aquela sociedade, ações de combate a crises econômicas que imponham compressões a direitos sociais, desde que resguardem o mínimo existencial a todos os cidadãos daquele Estado, baliza da dignidade da pessoa humana.

Não obstante, o reconhecimento de um maior espaço para restrições fracas a direitos sociais em momentos de crise econômica não representa, de forma alguma, uma total liberdade para o gestor público - nem mesmo para o legislador democraticamente eleito. Medidas de combate a crises econômicas não se inserem no âmbito puro das raisons de l'état, conceito do direito francês que traduz as razões tipicamente políticas do Estado e, portanto, infensas ao controle por mecanismos jurídicos - ideia que parece pouco se coadunar com o Estado Democrático de Direito. Além da observância ao núcleo essencial dos direitos fundamentais e ao mínimo existencial, as medidas de combate à crise econômica estão, também, sujeitas à fiscalização pelas instâncias de controle.

Na linguagem própria do discurso teubneriano, o direito, ainda que desenhado como um sistema autopoiético, é aberto a influências de outros sistemas sociais (como a economia), que inicialmente são percebidas como perturbações e irritações externas, mas, por meio de acoplamentos estruturais adequados, acabam filtradas e absorvidas pelos institutos que lhe são próprios. ${ }^{48} \mathrm{Ou}$ seja, as propostas formuladas pela economia para combater crises econômicas que geram repercussões jurídicas são, por meio desses acoplamentos, filtradas pelo direito e a ele incorporadas por meio de mecanismos típicos do sistema jurídico. Após essa internalização das medidas econômicas para dentro do sistema do direito, elas passam a integrá-lo e, com isso, são passíveis de serem controladas através dos mecanismos jurídicos. A partir daí, essas ações ficam submetidas ao crivo de todas as instâncias de controle, tanto por meio da sociedade civil quanto por meio de órgãos constitucionalmente investidos deste papel.

Dessa forma, mesmo durante grave crise econômica, eventuais compressões a direitos sociais levadas a cabo em contextos de austeridade e redução de gastos públicos não poderão pôr em risco a universalização

${ }^{48}$ TEUBNER, Gunther. O Direito como Sistema Autopoiético. Trad. José Engrácia Antunes. Lisboa: Fundação Calouste Gulbenkian, 1993, p. 74. 
das liberdades fundamentais, da educação básica, média e técnica, da saúde básica e da assistência aos desamparados. Caso contrário, implicariam restrições para além do mínimo existencial - o que, como visto, não pode ser admitido.

Já as constrições a direitos sociais que não representem violações ao mínimo existencial deverão ser sopesadas no caso concreto, levando-se em consideração, de um lado, o tamanho da necessidade fática que levou à sua edição e, de outro, a gravidade da restrição imposta. O grau dessa severidade pode ser aferido a partir da maior ou menor proximidade do direito objeto de restrição com o mínimo existencial, devendo-se optar pela efetivação de medidas que estejam mais distantes do núcleo duro da dignidade da pessoa humana e pela preservação, sempre que possível, de políticas ligadas a direitos mais próximos ao mínimo existencial.

É verdade que essa análise frequentemente é feita a partir do já conhecido teste da proporcionalidade ${ }^{49}$, incorrendo casuísmos que comprometem a objetividade do Direito, mas também se deve reconhecer que, até os dias atuais, tentativas de parametrização asséptica do estudo jurídico, por exemplo através do positivismo kelseniano, não produziram resultados socialmente desejáveis.

Sobre a proporcionalidade em momentos de crise, António Manuel Hespanha destaca:

Num contexto de crise, o argumento da proporcionalidade pode ser usado para apoiar a repartição igual dos sacrifícios, porque a crise seria igual para

${ }^{49} \mathrm{O}$ teste da proporcionalidade, formulado por Alexy, parte da ideia de que princípios são "mandados de otimização", que devem ser promovidos da melhor forma possível no caso concreto, subdividindo-a em adequação (a medida deve ser apta a alcançar a finalidade desejada), necessidade (não deve haver meios menos gravosos para atingir o mesmo resultado) e proporcionalidade em sentido estrito (os benefícios da medida devem superar seus custos). Assim, somente violará a ordem constitucional a medida anti-crise que violar a proporcionalidade, admitindo-se aquelas que não o façam. A proporcionalidade não deve funcionar como uma vedação apriorística às medidas anti-crise; em verdade, deve ser um parâmetro de análise da medida adotada para se verificar sua juridicidade. E, indo além, essa aferição deve levar em consideração o contexto em que a ação se insere, uma vez que a "necessidade" e a relação entre os custos e os benefícios (proporcionalidade em sentido estrito) da medida estarão intimamente ligadas ao cenário em que ela se insere. Vide: ALEXY, Robert. Teoría de los Derechos Fundamentales. Trad. Carlos Bernal Pulido. Madrid: Centro de Estúdios Políticos y Constitucionales, 2002.

3 JOURNAL OF INSTITUTIONAL STUDIES 2 (2017) 
todos, ou a diferenciação dos sacrifícios, segundo o diagnóstico que se fizer (i) dos diferenciados impactos negativos da crise (em proporção inversa); (ii) dos impactos positivos da sua superação (em proporção direta); (iii) das responsabilidades pela crise (em proporção direta). Vale também o argumento a partir da comparação entre os custos e os benefícios. Neste caso, o contexto da crise - de uma crise que se caracteriza como final e suprema, pondo em perigo tudo - pode servir para justificar o aumento dos sacrifícios até ao limite máximo, salvaguardando apenas o mínimo exigido por direitos fundamentais, não tanto porque a crise também não os ponha em causa, mas apenas porque o direito positivo não os pode sacrificar..$^{50}$

A ponderação realizada no âmbito da proporcionalidade deverá, pois, ter em mente o contexto de crise severa em que a medida foi levada a cabo, admitindo-se restrições a direitos sociais que não representem violações a seu núcleo duro nem ao mínimo existencial. Nesse sentido, a situação de crise econômica persistente funcionará, para o órgão de controle (em especial, o Poder Judiciário), como um vetor interpretativo da validade jurídica da medida, cabendo a este perquirir, sobretudo, se haveria meios menos gravosos (isto é, menos violadores à dignidade da pessoa humana) para alcançar o mesmo resultado (a saber, o reequilíbrio das contas públicas).

O lado negativo da atribuição de peso excessivo à proporcionalidade é o excessivo casuísmo - e até certo decisionismo - em que podem acabar incorrendo os tribunais superiores, como apontam Miguel Nogueira de Brito e Luís Pereira Coutinho. ${ }^{51} \mathrm{O}$ Tribunal Constitucional Português oferece um exemplo bastante interessante nesse ponto: o Acórdão no 396/2011 considerou constitucionais reduções nos salários dos servidores públicos sob o argumento da urgência e da necessidade da medida, ao passo que o Acórdão nº 353/2012 julgou inconstitucional a nova redução de $14,3 \%$ intentada no ano seguinte, por entender que a medida, somada à redução já efetivada, extrapolaria a razoabilidade e a proporcionalidade.

${ }^{50}$ HESPANHA, António Manuel. A revolução neoliberal e a subversão do "modelo jurídico": crise, direito e argumentação jurídica. In: Jorge Bacelar Gouveia e Nuno Piçarra (Orgs.). A Crise e o Direito. Coimbra: Almedina, 2013, p. 98-99.

${ }^{51}$ BRITO, Miguel Nogueira de; COUTINHO, Luís Pereira, A “Igualdade Proporcional": novo modelo no controlo do Princípio da Igualdade? Comentário ao Acórdão do Tribunal Constitucional n.. 187/2013. Direito \& Política, No. 4, 2013, p. 182 e ss. 
Em Portugal, o conjunto de decisões que analisam a juridicidade de medidas anti-crise recebeu o nome de jurisprudência da crise, a qual se caracteriza pelo reconhecimento de uma série de elementos extrajurídicos na ratio decidendi do Tribunal Constitucional, cujas decisões frequentemente citam dados fáticos e econômicos para chancelar políticas de austeridade bastante duras sobre a população.

No âmbito teórico, Marcelo Neves ${ }^{52}$ alerta para o risco de alopoiese do subsistema jurídico, representado pela sabotagem do código-diferença próprio do Direito (lícito/ilícito) por intervenções excessivas de outros subsistemas, notadamente a economia. A jurisprudência da crise parece apontar para a concretude deste risco, justamente por isso sendo vista com ressalvas por parte da doutrina portuguesa, como Luís Pereira Coutinho, que considera essa influência excessiva "um elemento perturbador". ${ }^{53}$

Com vistas a fornecer um parâmetro mais objetivo do que o mero casuísmo da proporcionalidade, a autora portuguesa Maria Benedita Urbano, em artigo destinado ao controle de políticas de combate a crises econômicas pelo Poder Judiciário, defende que o controle judicial dessas ações deve ser realizado com base no princípio in dubio pro medida anticrise. ${ }^{54}$ A autora prega uma maior deferência (strict scrutinity) do Judiciário às ações adotadas no âmbito de programas de combate a crises econômicas, privilegiando o programa político e econômico implementado por representantes eleitos por voto popular. Além disso, reconhece, ainda que de forma implícita, que a vocação maior do Poder Judiciário reside na microjustiça, na justiça do caso concreto, à luz da teoria das capacidades institucionais..$^{55}$

Assim, defende que as medidas anti-crise somente podem ser invalidadas se representarem uma violação flagrante à ordem vigente, devendo o Judiciário adotar uma postura de maior autocontenção quando a ação se situar em uma zona cinzenta de admissibilidade.

52 NEVES, Marcelo. Transconstitucionalismo. São Paulo, SP: WMF Martins Fontes, 2009 , p. 42

${ }^{53}$ COUTINHO, Luís Pereira. Os Direitos Sociais e a Crise: Breve Reflexão. Revista

Direito \& Política, No. 1, 2012, p. 81.

${ }_{54}^{4}$ URBANO, Maria Benedita. Estado de crise económica e financeira e o papel do Tribunal Constitucional. In: Pedro Gonçalves, et. al. (eds.). A Crise e o Direito Público. VI Encontro de Professores Portugueses de Direito Público. Lisboa: Instituto de Ciências Jurídico-Políticas, 2013.

55 Para aprofundamento do tema, ver: SUNSTEIN, Cass; VERMEULE, Adrian. Interpretation and Institutions. Michigan Law Review, Vol. 101, 4, 2003. 
Além disso, o Tribunal Constitucional Português, no Acórdão no $353 / 2012$, asseverou que, quanto maior o grau de sacrifício imposto ao cidadão para atender a interesses públicos, maiores são as exigências de equidade e justiça na repartição desses sacrifícios, afastando-se da ideia de que o Judiciário somente poderia anular decisões políticas se as considerasse evidentemente excessivas e dispensáveis..$^{56}$

Carlos Cano Ameyrich ${ }^{57}$ traz, ainda, outro parâmetro interessante para o controle judicial de medidas de combate a emergências

${ }^{56}$ Nas palavras de Carlos Cano Ameyrich, Professor Titular de Direito Administrativo da Universidade de Corunha: "Diga-se, em qualquer caso, que esta (auto)limitação no controlo não é incompatível, todo ao contrário, com a intensidade na aplicação dos parámetros escollidos. Porque a mesma excecionalidade e gravidade da crise económica, que salva a constitucionalidade de algumas das medidas de corte, é a que justifica um maior rigor na sua fiscalização, na ideia de que 'quanto maior é o grau de sacrifício imposto aos cidadãos para satisfação de interesses públicos, maiores são as exigências de equidade e justiça na repartição desses sacrifícios', afastando-se o tribunal, neste ponto, do parecer de uma minoría que advogaba por um 'control mínimo' a partir da idea de que quando a diferenciação realizada pelo legislador não violar expressamente uma prohibição de discriminação explicitada na Constitução - e tal seria o caso do tratamento diferenciado dispensado pelas lei do orçamento e quem aufere por verbas públicas - a justiça constitucional só pode anular as decisões do legislador para o caso de estas se mostrarem, à evidência, excessivas ou dispensáveis. Este rigor material exigido pelo TCP encontra o seu correlato procesual na ideia, formulada por PISARELLO, do controlo judicial não como uma via para o desenho de políticas públicas concretas (assumindo deste jeito a justiça uma tarefa que, em virtude do princípio democrático, deve corresponder ao legislativo) mas como espaço no qual discutir mejor, con mayor información y con mayor implicación de los afectados, la calidad democrática y la sensibilidad garantista de las políticas públicas existentes". AMEYRICH CANO, Carlos. O Controlo Judicial das Políticas de Austeridade: a propósito do Acordão 187/2013, de 5 de Abril, do Tribunal Constitucional Português. Disponível em:

$<$ https://www.academia.edu/4533780/Controlo judicial das pol\%C3\%ADticas de aus teridade>. Acesso em: 04 de fevereiro de 2018. A redação original do texto foi mantida, não tendo sido possível apurar se se trata de algum dialeto galego (já que o autor é professor da Universidade de Corunha) ou de uma tentativa do autor, hispanófono, de escrever em português. As fontes do texto, porém, foram conferidas e pareceram acuradas.

${ }^{57}$ AMEYRICH CANO, Carlos. O Controlo Judicial das Políticas de Austeridade: a propósito do Acordão 187/2013, de 5 de Abril, do Tribunal Constitucional Português. Disponível em: 
econômicas, na esteira da preocupação com a legitimidade democrática da atuação pública, especialmente cara ao Estado Democrático de Direito: quanto menor é a participação e debate na elaboração da norma e maiores os sacrifícios que ela impõe, mais incisivo e exigente deve ser o controle judicial, como garantia última de vigência dos direitos e princípios constitucionais afetados.

Nesse sentido, em uma tentativa de conciliar as ideias que expusemos ao longo dos últimos parágrafos, defendemos a possibilidade de controle das medidas anti-crise econômica que imponham constrições a direitos sociais, principalmente quando esses sacrifícios se mostrarem especialmente pesados. No entanto, a efetiva invalidação fica sujeita a um escrutínio estrito, devendo o Judiciário mostrar deferência à medida caso ela não viole o mínimo existencial (i.e., não represente violação patente a preceito constitucional), possa ser justificada à luz das necessidades públicas que levaram à sua edição, tenha sido submetida a amplo debate democrático e, ainda, os ônus impostos pelo conjunto de medidas anticrise tenham sido repartidos pela sociedade em observância à equidade.

\section{HAVERIA ESPAÇO PARA RESTRIÇÕES FORTES?}

Muito embora a restrição a direitos sociais em momentos de crise grave comporte juridicamente uma versão fraca, limitada pela dignidade da pessoa humana, é possível que a crise seja tão profunda e persistente que as medidas implementadas no primeiro momento (em observância aos limites trazidos pela garantia ao mínimo existencial) não sejam suficientes para superá-la. Nesse caso, a gravidade dos fatos pode levar à cogitação de medidas que representem restrições fortes a direitos, em que as ações implementadas invadam direitos sociais para além do mínimo existencial.

Esse tipo de ação somente será juridicamente possível caso previamente reconhecido, pelo procedimento constitucionalmente estabelecido, algum tipo de estado de exceção, não se admitindo a implementação, no estado de normalidade, de medidas que invadam o núcleo da dignidade da pessoa humana. A decretação de estados de exceção deve ser disciplinada pela Constituição, que trará o rol taxativo de situações que admitirão a sua implantação, assim como os direitos que poderão ser restringidos durante o período excepcional.

$<$ https://www.academia.edu/4533780/Controlo judicial das pol\%C3\%ADticas de aus teridade $>$. Acesso em: 04 de fevereiro de 2018.

3 JOURNAL OF INSTITUTIONAL STUDIES 2 (2017) 
É importante que o rol de direitos essenciais passíveis de restrição durante a vigência do estado de exceção esteja previsto de maneira exaustiva no texto constitucional, dada a seriedade da medida. Afinal, o estado de exceção não pode ser anormativo nem ajurídico ${ }^{58}$ - em outras palavras, não pode ser um buraco negro.

Além disso, somente no caso de a Constituição do país admitir a deflagração de estado de exceção por motivos econômicos é que será possível a sua implantação nesses momentos, uma vez que as normas que restrinjam direitos fundamentais devem ser interpretadas sempre de forma restritiva.

No Brasil, a Constituição da República de 1988 traz duas espécies de estados de exceção: o de sítio e o de defesa. O estado de defesa pode ser decretado pelo Presidente da República, ouvidos o Conselho da República e o Conselho de Defesa Nacional, com o propósito de preservar ou prontamente restabelecer, em locais restritos e determinados, a ordem pública ou a paz social ameaçadas por grave e iminente instabilidade institucional ou atingidas por calamidades de grandes proporções na natureza. ${ }^{59}$

Já o estado de sítio demanda autorização prévia do Congresso Nacional, a qual poderá ser solicitada pelo Presidente da República nos casos de: (i) comoção grave de repercussão nacional ou ocorrência de fatos que comprovem a ineficácia de medida tomada durante o estado de defesa; ou (ii) declaração de estado de guerra ou resposta a agressão armada estrangeira. ${ }^{60}$

A decretação dos estados de defesa e de sítio está sujeita à valoração de conceitos jurídicos indeterminados, como ordem pública, paz social, grave e iminente instabilidade institucional e comoção grave de repercussão nacional. Na aplicação de conceitos jurídicos indeterminados, há margem para interpretação por parte do aplicador da norma, assim como existe espaço para uma zona cinzenta, em que não será possível afirmar peremptoriamente se a situação posta está ou não abrangida pelo conceito indeterminado em questão. ${ }^{61}$

${ }^{58}$ GOUVEIA, Jorge Bacelar; PIÇARRA, Nuno (Orgs.). A Crise e o Direito. Coimbra: Almedina, 2013, p. 185.

${ }^{59}$ Constituição da República, art. 136.

${ }^{60}$ Constituição da República, art. 137.

${ }^{61}$ Para aprofundamento sobre a aplicação de conceitos jurídicos indeterminados, vide: KRELL, Andreas Joachim. Discricionariedade Administrativa e Conceitos Legais Indeterminados: Limites do controle judicial no âmbito dos interesses difusos. $2^{\underline{a}}$ ed. Porto Alegre, RS: Livraria do Advogado, 2013. 
Nessa esteira, é admissível momentos de crise econômica possam ensejar grave e iminente instabilidade institucional ou comoção grave de repercussão nacional, situações aptas a legitimar o reconhecimento de um Estado de exceção. Por exemplo, a crise dura e prolongada pode originar saques generalizados e episódios de violência que cheguem à beira de uma guerra civil. Assim, desdobramentos da crise que possam ser enquadrados dentro da moldura dos conceitos jurídicos indeterminados que autorizam estados de exceção poderão servir de fundamento para a decretação de estado de defesa pelo Presidente da República ou para o pedido de autorização, pelo Presidente da República, ao Congresso Nacional para decretação de estado de sítio.

Na vigência do estado de defesa, são autorizadas ${ }^{62}:$ (i) a restrição dos direitos de reunião, sigilo de correspondência, sigilo de comunicação telegráfica e telefônica; e (ii) na hipótese de calamidade pública, a ocupação temporária de bens e serviços públicos. Já no estado de sítio será possível a implementação de ${ }^{63}$ : (i) obrigação de permanência em determinada localidade; (ii) detenção em edifício não destinado a acusados ou condenados por crimes comuns; (iii) restrições relativas à inviolabilidade da correspondência, ao sigilo das comunicações, à prestação de informações e à liberdade de imprensa, radiodifusão e televisão; (iv) suspensão da liberdade de reunião; (v) busca e apreensão em domicílio; (vi) intervenção nas empresas de serviços públicos; e (vii) requisição de bens.

Observa-se, portanto, que as medidas autorizadas pelo Constituinte Brasileiro na vigência dos estados de defesa e de sítio relacionam-se precipuamente a direitos e garantias individuais, não havendo maior espaço para restrições a direitos sociais. Ainda que seja viável a decretação de estado de exceção em razão de instabilidades institucionais decorrentes de grave crise econômica, na ordem constitucional vigente, não seria possível a restrição a direitos sociais para além do mínimo existencial e do núcleo essencial mesmo na vigência de estados de exceção, já que nosso Texto Maior não admite restrições desta natureza nem no estado de defesa nem no de sítio. ${ }^{64}$

${ }^{62}$ Constituição da República, art. 136, §1º.

${ }^{63}$ Constituição da República, art. 137.

${ }^{64}$ A título ilustrativo, destacamos que outras Constituições, como a portuguesa, sequer admitem a decretação de estado de exceção em razão de eventos de cunho econômico. Como destaca António Manuel Hespanha, “o Estado de exceção está previsto na Constituição da República Portuguesa no art. 19º, que se refere à suspensão do exercício de direitos. Ao contrário do que acontece com algumas constituições contemporâneas, a Constituição [Portuguesa] não prevê a declaração de um estado de 
Todavia, não obstante os parâmetros aqui delineados, é possível que, na prática, não haja recursos disponíveis para efetivar a decisão que determina a garantia do mínimo existencial. Nessas situações, afirmar que o mínimo existencial não pode ser violado não faz com que automaticamente surjam em caixa recursos para atendê-lo, mas, por outro lado, caberá a responsabilização do ente público e dos administradores públicos envolvidos, principalmente aqueles cujas decisões tenham sido determinantes para a configuração do contexto de escassez absoluta de recursos.

Essa responsabilização pode se dar tanto na esfera civil, à luz da omissão no dever de cumprir com o mínimo existencial, quanto na esfera da improbidade administrativa, à luz da violação a princípios administrativos (e, eventualmente, do dano ao erário, quando comprovado que alguma conduta do gestor contribuiu com a situação), sendo certo que, no primeiro caso, a responsabilidade recai a princípio sobre o ente público, haja vista a aplicação da teoria do órgão, ao passo que, no segundo caso, a responsabilidade recai sobre o agente político (isto é, sobre a pessoa física do gestor).

A questão da imposição de responsabilidade ao ente público se torna especialmente tormentosa no cenário em que não há caixa disponível para fazer frente a despesas determinadas judicialmente, o que traz novamente a lume debates em relação ao pragmatismo jurídico como um balizador de medidas anti-crise. Nesse caso, a imposição de obrigações de fazer, sanções por danos morais ou astreintes - ainda que robustas -, não é suficiente para materializar recursos que simplesmente não existem, dando azo ao que José Vicente Santos de Mendonça denomina de quixotismo judiciário ${ }^{65}$, isto é, decisões judiciais sabidamente

exceção por razões económico-financeiras". HESPANHA, António Manuel. A revolução neoliberal e a subversão do "modelo jurídico": crise, direito e argumentação jurídica. In: Jorge Bacelar Gouveia e Nuno Piçarra (Orgs.). A Crise e o Direito. Coimbra: Almedina, 2013, p. 56-57.

65 “O quixotismo judiciário é o irmão da insinceridade decisória. São as multas de centenas de milhões de reais para pessoas físicas; as ameaças de prisão de secretários de saúde em recusas de remédios. É o Judiciário fazendo-se de tigre de papel. A coisa toda se passa como num jogo surreal, em que nem o juiz vai prender, nem o secretário vai ser preso, mas todos agem como se isso fosse possível e provável. MENDONÇA, José Vicente Santos de; RECONDO, Felipe. Quixotismo Judiciário: o caso WhatsApp. JOTA, 17 dez. 2015. Disponível em: $<$ http://jota.info/quixotismo-judiciario-o-casowhatsapp>. Acesso em: 04 de fevereiro de 2018. Na mesma esteira, o Governador Luiz Fernando Pezão deu entrevistas após as decisões acima comentando ironicamente que, 
incumpríveis e completamente desprovidas de qualquer senso de realidade.

Por esse motivo, entendemos que deve haver uma primazia pela responsabilização pessoal do gestor público, seja na esfera civiladministrativa, seja na esfera da improbidade administrativa (desde que, evidentemente, reste comprovada a existência de alguma conduta deste que tenha contribuído com a instalação e/ou o agravamento da situação de crise), na medida em que, em um contexto no qual as finanças públicas já se encontram especialmente combalidas, impor ainda mais obrigações pecuniárias e/ou prestacionais ao Estado não parece contribuir em muito - em verdade, em quase nada - para que o ente se reorganize.

\section{CONCLUSÕES}

Diante do exposto, podemos concluir pela existência de espaços de conformação para a atuação do poder público em momentos de combate a crises econômicas. Não se pode considerar que a vedação do retrocesso, a isonomia e a proteção à confiança legítima levam à invalidação automática de toda e qualquer ação governamental que implique restrições a direitos sociais em contextos de recessão grave e duradoura.

À luz do pragmatismo e da versão fraca da proteção à confiança (que somente considera legítima a expectativa que se baseie no mesmo contexto), o direito deve ser permeado pela realidade em que ele se insere e, em momentos de crise econômica prolongada, a disponibilidade orçamentária para a desenvolvimento de políticas públicas de modo geral - inclusive aquelas voltadas à promoção de direitos sociais - sem dúvida resta comprometida.

Isso não significa, no entanto, que as medidas anti-crise devam ser encaradas como buracos negros, isto é, como espaços ajurídicos. É possível oferecer parâmetros para a validade de ações que imponham restrições a direitos sociais, dentre os quais cabe destacar a proteção ao mínimo existencial e o grau de debate desenvolvido com a sociedade civil antes de sua implementação.

Assim, as medidas adotadas somente poderão ser consideradas válidas se não violarem este mínimo existencial - que, para nós, é composto de liberdades fundamentais e direitos sociais à educação

juntamente com a intimação, o Judiciário poderia enviar ao Estado um carro-forte para fazer frente às despesas por elas impostas. Disponível em:

$<$ http://oglobo.globo.com/rio/pezao-ironiza-decisoes-da-justica-afirma-que-vairecorrer-de-liminares-18362390>. Acesso em: 17 de outubro de 2017. 
básica, média e técnica, saúde básica e assistência aos desamparados -, dando-se preferência àquelas que (i) tenham sido precedidas de ampla discussão com a população, sobretudo aquela diretamente afetada e (ii) reparam com equidade os ônus decorrentes do contexto de crise.

Assim, mesmo no caso de medidas não violadoras do núcleo duro da dignidade humana, a proximidade da política adotada com o mínimo existencial deverá servir de vetor para a análise da sua validade. É dizer: quando da adoção de ações de enfrentamento a crises econômicas, o gestor deve perquirir se haveria alternativas menos gravosas à dignidade da pessoa humana, levando em conta se o direito a ser objeto de restrição encontra-se mais ou menos próximo do mínimo existencial.

Além disso, cabe reconhecer que essa análise acerca da juridicidade das ações anti-crise sujeita-se a um escrutínio estrito, de maneira que, em caso de dúvida quanto à sua validade, e medida deve ser preservada, haja vista a severidade do contexto em que se insere. A esta formulação, a doutrina portuguesa denomina in dubio pro medida anti-crise.

Constrições de direitos sociais para além do mínimo existencial somente seriam admitidas caso expressamente declarado o estado de exceção. Contudo, esse estado excepcional somente pode ser declarado dentro das hipóteses constitucionalmente previstas e apenas poderá restringir aqueles direitos expressamente arrolados no texto constitucional. $\mathrm{Na}$ atual ordem brasileira, embora uma dura crise econômica possa servir de fundamento, a partir de conceitos jurídicos indeterminados, à declaração de estado de exceção, não seria possível a restrição de direitos sociais, tendo em vista que estes não estão previstos no rol dos arts. 136 e 137 da Constituição da República de 1988 como passíveis de compressão durante os estados de defesa e de sítio.

No caso, porém, de ter sido adotada uma medida que invada o mínimo existencial, será possível a sua invalidação pela via administrativa (autotutela) ou judicial e, ainda, eventual responsabilização civil do ente público e responsabilização civiladministrativa e/ou por improbidade administrativa do agente político.

É evidente que o reconhecimento da invalidade da medida não faz surgirem em caixa os recursos necessários à promoção do mínimo existencial, motivo pelo qual, não obstante seja possível a responsabilização do ente público em situação de violação ao núcleo essencial da dignidade da pessoa humana, entendemos que, para se não incorrer em quixotismo judiciário, nesses casos, o debate jurídico deve dividir-se em duas frentes.

$\mathrm{Na}$ primeira, deve-se buscar, juntamente com a sociedade civil, mecanismos para um enfrentamento mais sério da situação de crise, buscando-se alternativas de reequilíbrio das contas públicas que 
assegurem maior proteção ao mínimo existencial, com o redimensionamento de políticas de governo mais distantes deste núcleo duro. Na segunda, deve-se dar preferência à responsabilidade civiladministrativa e/ou por improbidade dos agentes políticos cujos comportamentos tenham, por dolo ou culpa, contribuído sensivelmente para a deterioração das finanças públicas, em detrimento da responsabilização da pessoa jurídica, a fim de evitar uma deterioração ainda maior das contas do governo.

\section{REFERÊNCIAS}

ACKERMAN, Bruce. The Emergency Constitution. Yale Law Journal, Vol. 113, 5, 2004.

ALEXY, Robert. Teoría de los Derechos Fundamentales. Trad. Carlos Bernal Pulido. Madrid: Centro de Estúdios Políticos y Constitucionales, 2002.

AMEYRICH CANO, Carlos. O Controlo Judicial das Políticas de Austeridade: a propósito do Acordão 187/2013, de 5 de Abril, do Tribunal Constitucional Português. Disponível em: $<$ https://www.academia.edu/4533780/Controlo judicial das pol\%C3\%A Dticas de austeridade>. Acesso em: 04 de fevereiro de 2018.

BARCELlOS, Ana Paula de. A Eficácia Jurídica dos Princípios Constitucionais: o Princípio da Dignidade da Pessoa Humana. $2^{\underline{a}}$ ed. Rio de Janeiro, RJ: Renovar, 2008.

A Eficácia Jurídica dos Princípios Constitucionais: o Princípio da Dignidade da Pessoa Humana. $3^{a}$ ed. Rio de Janeiro, RJ: Renovar, 2011. 
BARROSO, Luís Roberto. A Dignidade da Pessoa Humana no Direito Constitucional Contemporâneo: natureza jurídica, conteúdos mínimos e critérios de aplicação. Interesse Público, Vol. 14, 76, 2012.

. A Doutrina Brasileira da Efetividade. Temas de Direito

Constitucional. Tomo III. Rio de Janeiro, RJ: Renovar, 2005.

. Interpretação e Aplicação da Constituição: fundamentos de uma dogmática constitucional transformadora. $7^{a}$ ed. São Paulo, SP, RJ: Saraiva, 2009.

. O Direito Constitucional e a Efetividade de suas Normas: limites e possibilidades da Constituição Brasileira. $6^{\underline{a}}$ ed. Rio de Janeiro, RJ: Renovar, 2002.

BRITO, Miguel Nogueira de; COUTINHO, Luís Pereira, A “Igualdade Proporcional": novo modelo no controlo do Princípio da Igualdade? Comentário ao Acórdão do Tribunal Constitucional n. ${ }^{\circ}$ 187/2013. Direito \& Política, No. 4, 2013.

CANOTILHO, J.J. Gomes. Direito Constitucional e Teoria da Constituição. $4^{\mathrm{a}}$ ed. Coimbra: Almedina, 2000.

COOTER, Thomas F. Legal Pragmatism and the Law and Economics Movement. Georgetown Law Journal, Vol. 84, 6, 1996.

COUTINHO, Luís Pereira. Os Direitos Sociais e a Crise: Breve Reflexão. Revista Direito \& Política, No. 1, 2012.

DERBLI, Felipe. O Princípio da Proibição do Retrocesso Social na Constituição de 1988. Rio de Janeiro, RJ: Renovar, 2007. 
DYZENHAUS, David. Schmitt V. Dicey: Are States of Emergency Inside or Outside the Legal Order? Cardozo Law Review, Vol. 27, p. 2005, ano 2008.

DWORKIN, Ronald. A Raposa e o Porco-Espinho: Justiça e Valor. Trad. de Marcelo Brandão Cipolla. São Paulo, SP: WMF Martins Fontes, 2014.

FALSARELLA, Christiane. Reserva do Possível como aquilo que é razoável se exigir do Estado. Disponível em:

$<$ http://www.apesp.org.br/comunicados/images/tese christiane mina o ut2012.pdf $>$. Acesso em: 17 de outubro de 2017

GOUVEIA, Jorge Bacelar. Da Constituição da Crise à Crise da Constituição. In: Jorge Bacelar Gouveia e Nuno Piçarra (Orgs.). A Crise e o Direito. Coimbra: Almedina, 2013.

GOUVEIA, Jorge Bacelar; PIÇARRA, Nuno (Orgs.). A Crise e o Direito. Coimbra: Almedina, 2013.

GRAU, Eros. A Emenda Constitucional no 30/00: pagamento de precatórios judiciais. Revista de Direito Administrativo, No. 229, 2002

HESPANHA, António Manuel. A revolução neoliberal e a subversão do "modelo jurídico": crise, direito e argumentação jurídica. In: Jorge Bacelar Gouveia e Nuno Piçarra (Orgs.). A Crise e o Direito. Coimbra: Almedina, 2013.

HESSE, Konrad. La fuerza normativa de la Constitución. In: Konrad Hesse. Escritos de Derecho Constitucional. Trad. Pedro Cruz Villalón. Madrid: Centro de Estudios Constitucionales, 1983.

KRELL, Andreas Joachim. Discricionariedade Administrativa e Conceitos Legais Indeterminados: Limites do controle judicial no 
âmbito dos interesses difusos. $2^{\underline{a}}$ ed. Porto Alegre, RS: Livraria do Advogado, 2013.

LASSALLE, Ferdinand. O que é uma Constituição? Belo Horizonte, MG: Líder, 2004.

MENDONÇA, José Vicente Santos de; RECONDO, Felipe. Quixotismo Judiciário: o caso WhatsApp. JOTA, 17 dez. 2015. Disponível em: $<$ http://jota.info/quixotismo-judiciario-o-caso-whatsapp $>$. Acesso em: 04 de fevereiro de 2018.

MEYLER, Bernadette. Economic Emergency and the Rule of Law. De Paul Law Review, Vol. 56, 2, 2007.

NEVES, Marcelo. Transconstitucionalismo. São Paulo, SP: WMF Martins Fontes, 2009.

O'DONNELL, Guillermo. Dissonances: Democratic Critiques of Democracy. Notre Dame: University of Notre Dame Press, 2007.

OTERO, Paulo. A crise: um novo direito administrativo? In: Jorge Bacelar Gouveia e Nuno Piçarra (Orgs.). A Crise e o Direito. Coimbra: Almedina, 2013.

POSNER, Eric; VERMEULE, Adrian. Crisis Governance in the Administrative State: 9/11 and the Financial Meltdown of 2008. University of Chicago Law Review, Vol. 76, 4, 2009.

POSNER, Richard. Law, Pragmatism and Democracy. Cambridge, MA: Harvard University Press, 2005. . The Problems of Jurisprudence. Cambridge, MA: Harvard University Press, 1993. 
RAMOS, Marcelo Valença. Releitura sistêmico-teórica das relações entre direito, política e economia: a crise de $\mathbf{2 0 0 8}$ como ponto de inflexão para a emergência do constitucionalismo societal. 190 f. 2014. Dissertação (Mestrado em Direito), Programa de Pós-Graduação em Direito da Universidade Estadual do Rio de Janeiro, Universidade Estadual do Rio de Janeiro, Rio de Janeiro, RJ, 2014.

RUFFERT, Matthias (ed.). Administrative Law in Europe: between Common Principles and National Traditions. Groningen: Europa Law Publishing, 2013.

SARLET, Ingo Wolfgang; FIGUEIREDO, Mariana Filchtiner. Reserva do Possível, Mínimo Existencial e Direito à Saúde: algumas aproximações. Revista de Doutrina da $4^{\mathrm{a}}$ Região, No. 24, 2008. Disponível em: $<$ http://www.revistadoutrina.trf4.jus.br/index.htm?http://www.revistad outrina.trf4.jus.br/artigos/edicao024/ingo mariana.html>. Acesso em: 04 de fevereiro de 2018.

. Direito Fundamentais Sociais e Proibição do Retrocesso: algumas notas sobre o desafio da sobrevivência dos Direitos Sociais num contexto de Crise. Revista da Ajuris, Ano XXXI, No. 95, 2004.

SILVA, José Afonso da. Comentário Contextual à Constituição. $7^{7}$ ed. São Paulo: Malheiros, 2010.

SOUZA NETO, Cláudio Pereira de; SARMENTO, Daniel. Direito Constitucional: Teoria, História e Métodos de Trabalho. 2a ed. Belo Horizonte: Fórum, 2014.

SUNSTEIN, Cass; VERMEULE, Adrian. Interpretation and Institutions. Michigan Law Review, Vol. 101, 4, 2003.

TEUBNER, Gunther. O Direito como Sistema Autopoiético. Trad. José Engrácia Antunes. Lisboa: Fundação Calouste Gulbenkian, 1993. 
TORRES, Ricardo Lobo. O Direito ao Mínimo Existencial. Rio de Janeiro, RJ: Renovar, 2009.

URBANO, Maria Benedita. Estado de crise económica e financeira e o papel do Tribunal Constitucional. In: Pedro Gonçalves, et. al. (eds.). A Crise e o Direito Público. VI Encontro de Professores Portugueses de Direito Público. Lisboa: Instituto de Ciências Jurídico-Políticas, 2013.

VERMEULE, Adrian. Our Schmittian Administrative Law. Harvard Law Review, Vol. 122, 4, 2009.

Crise Econômica e Direitos Sociais: uma análise sobre a Constitucionalidade de restrições a Direitos Prestacionais

Economic Crises and Social Rights: an analysis of the constitutionality of positive rights restrictions Submetido em: 2017-10-23 Aceito em: 2017-12-26 